\title{
THE CLASSIFICATION OF INTERNATIONAL ORGANIZATIONS, II
}

\author{
PITMAN B. POTTER \\ Institut Universitaire de Hautes Etudes Internationales, Geneva
}

\begin{abstract}
$\mathrm{V}$
In any work of classification, the selection of standards is, of course, of primary importance. In the budget of the League, absurd results appear at various points as a result of arranging the contents thereof now according to one type of standard (subjectmatter, as "Mandates"), now according to another (kind of service, as "Liaison"). ${ }^{51}$ Without coördinate and mutually exclusive standards, no classification can be complete or satisfactory.

One or two of the points made above might, it is obvious, be used as indices of classification if not used as grounds of exclusion. That is, if unofficial international organizations are not excluded entirely, as they logically should be, from this study, they might form one of the two classes of international organizations, along with official organizations. Similarly, organizations may be classified as bilateral and multilateral, in accord with the foregoing discussion, as resting upon mere practice or formal convention, as intended for the observance of some principle or for the taking of some overt action, and finally as relying upon national agencies for their operation or possessing agencies of their own. For our purpose, however, from this point onward, we shall assume that the organizations with which we deal are official multilateral organizations resting upon conventional constitutions and possessing agencies of their own, albeit what is said by way of further classification will, as a matter of fact, apply to the others to a large extent also.
\end{abstract}

Now the distinguishing characteristic of official international organizations, and their fundamental purpose, lies in their functioning as institutions for international government, for the exercise of control by one or more states over one another. Without arguing the logical possibility of "international government" here, ${ }^{52}$ it may be averred simply that these organizations aim at action and results which, in spite of theoretical objections to the

${ }^{51}$ Budget for 1933, as cited above, note 8 .

${ }^{52}$ See discussion in this Review, Vol. 25, p. 713 (Aug., 1931). 
contrary, are in fact identical with those involved in the practice of government as such, i.e., control of certain individuals or groups by other individuals or groups.

But the practice of government may be carried on along entirely arbitrary lines. That is, the governors may govern at their own entire discretion or caprice, and absolute monarchs and dictators sometimes do so. For various reasons, however, chiefly to reduce the opposition of the governed, and give the activity a seemingly higher ethical tone, the consent of the governed is now usually sought and government conducted according to accepted law. The process of government then becomes one of making and applying the law.

This all leads to an entirely familiar analysis of governmental activities, which turns upon the relations between those activities, individually, and the element of law in the situation, namely, as legislative (law-making), executive or administrative (law-applying), and judicial, the judicial function constituting in fact a phase of the administrative and consisting largely of discovering and declaring what the law is on a given question arising in the course of administrative activity as a result of resistance thereto on the part of someone to whom the law is supposed to apply, and of assisting in the application of the law in that case. ${ }^{53}$ This analysis is trite to the last degree, of course, but it must be recalled here because of the use which may have to be made of it in the classification of international organizations. ${ }^{54}$

${ }^{53}$ The similarities or differences between administration and adjudication cannot be discussed in full here, and what follows would not be greatly altered if the treatment of adjudication as a phase of administration were rejected. But in addition to what is suggested in the text it may be recalled, on the one hand, that administrative officials always have the task, deemed so peculiarly judicial in character, of discovering what the law is upon a given matter and what it means in that connection, while, on the other, the court has to perform two other, characteristically administrative, tasks, namely, to discover the facts of the case in their exact detail and to formulate a judgment applying the law (which it has discovered) aptly thereto-by order or decree or what not. See also, from the international point of view, the subservience of national courts to national legislative bodies where alleged conficts between national and international law arise: American Journal of International Law, Vol. 19, p. 315 (April, 1925). Similarly for the distinction, if any, to be made between "executive" and administrative action; in so far as they differ, the former seems to retain more of the element of policy-determination than the latter, the latter to come upon the scene only when all need for this has been met. See below, near note 72 .

${ }^{64}$ This analysis assumes, obviously, that law consists of propositions conscious- 
International organizations may indeed be classified with some success and advantage according to this standard. Thus a given international conference may be classified as legislative, a given international bureau as administrative, a court as judicial. All through the materials cited occur examples of institutions of these varieties, and the classification is so obvious and so familiar that it seems to amount to very little-this in spite of the fact that the necessity for ratification and the absence of sanctions deprive conferences on one point, and bureaus and courts on the other, of full status as legislative and administrative agencies, without, as is believed, destroying their position entirely.

Similarly, the generic institutions of international coöperation may be classified in this manner: conference as such, administrative bodies in general, international courts as a whole. The only danger to be encountered by such a procedure lies in the fact that within these fields the concrete examples vary somewhat from the typical. But inasmuch as in the preceding paragraph numerous concrete examples, when taken by themselves, reveal an overlapping of two or more functions, this mode of analysis seems as sound or accurate as the other. Thus the treatment or classification of such institutions in various writings on international organization today is sustained..$^{55}$

ly accepted by the parties thereto, and legislation of that process of acceptance. The fundamental conditions of life doubtless imply what rules should be adopted, but without that rational and volitional action those facts would remain outside the sphere of consciousness, the characteristic element of all social organization and action. It is necessary to go back of the law itself to find its origin, it has been truly said (Triepel, quoted by J. L. Brierly, in Académie de Droit International, Receuil des Cours, Vol. 23, p. 546), but the act of consent does lie outside of or behind the law, and it is to this last step before the appearance of the law, not to a more remote antecedent condition, that the student must go in his search. What is right or legal, what is law, in the sense of social life, is not what is harmonious with the conditions of life, and serviceable to man, but what is considered by men as harmonious therewith, or, at the most remote test, in accordance with the procedure adopted for determining this concordance. These positions will be accepted by all positivists without difficulty; at all events, they will be used as the basis for what follows.

${ }^{55}$ C. Eagleton, International Government (1932), pp. xi, xii; E. C. Mower, International Government (1931), pp. xv-xvi. For the sake of simplicity and brevity, the commission, or general or interim committee-an organ often found standing between conference and bureau in various unions-is ignored here. It is usually composed of national representatives rather than truly international agents and possesses legislative power as well as supervisory administrative power, but when compared with conference and bureau it appears as anomalous or ambiguous in character. See above, note 53 . 
It will be recalled that the legislative-administrative classification turns upon the employment of law in government. This being the case, there is no room in this classification for forms of international coöperation which are pre-legal or pre-institutional. Thus diplomacy, which consists largely of negotiation and representation upon subjects not yet covered by legal regulation, falls chiefly in this position, although in so far as diplomats and consuls share in the making and application of international law and treaty agreements, they share in legislative and administrative (and even judicial) work, respectively. Likewise international law and treaties, which create unions, hardly rank on a plane with those unions themselves, even though they do create them and are in turn used as tools by such unions and their agencies. ${ }^{56}$

The proper classification of international organizations by this standard involves also, it seems, a problem of order of treatment. The proper relating of diplomacy and international law to this standard is, as has just been indicated, not simple. So also, it seems, difficulties arise in placing the element of sanctions in its proper place in the general scheme of things, and even in relating international legislation properly to diplomacy and conference, in placing alliances and concerts in their proper position, and so on. These questions cannot be discussed fully in this essay on classification, but they must be noted as phases or aspects. ${ }^{57}$

Much more difficult problems, however, lie beneath the surface here. Even if an organization or agency be clearly legislative, administrative, or judicial, it may not be clearly internationally legislative, internationally administrative, internationally judicial; and this not because of the presence of national, or the absence of international, elements in its membership, but for reasons connected with its activity. The case of the international court may be considered first, and then that of the administrative agency, and finally the conference.

When is a court entitled to be regarded as an international court? When (and only when) it applies international law? ${ }^{58}$ But courts established by national authority apply international law,

s6 P. B. Potter, International Organization (3rd ed., 1928), p. 80.

${ }^{57}$ Review of Mower in Political Science Quarterly, Vol. 47, No. 3 (Sept., 1932).

${ }_{88}$ The law being defined as international by reference to its source, not its subject-matter or parties holding rights under it. See P. B. Potter, Manual Digest of Common International Law (1932), p. 5, etc. 
which is regarded as operative within the individual state upon and through these bodies, ${ }^{59}$ and courts acting upon international authority apply national law when under international law this is required $; 60$ nor does the supersophisticated interpretation of these situations to the effect that the international law becomes national law in the former case and the national law, international law in the latter case seem to alter the situation. When (and only when) it deals with parties of divergent nationalities? But nationally-created courts deal with such parties ${ }^{61}$ and it is at least conceivable that courts resting upon international mandate may handle cases between parties of the same nationality. ${ }^{62}$ It would seem that the source of authority is the only safe test for the international character of the court, even though that may leave room for the possible handling by such courts of rare cases between parties of the same nationality and according to national law

In the field of administration, the situation is slightly different. International administrative agencies seldom apply national law (though they do at times), ${ }^{63}$ but national administrative agencies constantly give effect to international law, both customary and conventional. ${ }^{64}$ Are they, therefore, to be regarded as international institutions? Such international agencies operate upon states as such, ${ }^{65}$ as do international tribunals, but they also operate upon private individuals, ${ }^{66}$ nationals of only one state at the time. Does this affect their status as international bodies?

So, finally, for international conferences. They are most purely international in character, yet exhibit certain flaws. For example, such conferences deal with problems or questions of national conditions and interest only remotely international in character, and the line between domestic and international questions is by no means clear. ${ }^{67}$ They reach results at times which call for national

${ }^{69}$ Same, pp. 74 and 170-171, esp. 170, note 195.1 .

${ }^{60}$ Permanent Court of International Justice, Publications, Series A, No. 21.

${ }^{61}$ See Constitution of the United States, Art. III, sect. 2, cl. 1.

${ }^{62}$ Compare International Labor Organization Constitution, Art. 409.

${ }^{63}$ See various provisions in the Convention of Mannheim governing nagivation of the Rhine, and creating and empowering the Central Commission (e.g., Arts. XXII, XXXIV, XLIII), in British and Foreign State Papers, Vol. LIX, p. 470.

${ }^{64}$ See above, note 59.

${ }^{65}$ See powers of Rhine River Commission in Treaty of Versailles, Art. 359.

${ }^{66}$ Same, Art. 356.

${ }^{67}$ For example, the financial reconstruction of Austria. See League of Nations, Secretariat, Ten Years of World Coöperation (1930), pp. 183-189; also Bureau In- 
rather than international action, that is, action of a state upon its own nationals having only indirect international results. ${ }^{68}$ And at times they are called in such a way and conducted in such a way that even these fundamental elements in their nature seem slightly less than truly international. ${ }^{69}$

The proper answer in the last two cases seems, nevertheless, to run along with that given for international courts. The source of the mandate is the test. Even if a commission or a conference were to be composed entirely of nationals of one state, as not infrequently happens in the case of international tribunals, ${ }^{70}$ the organ is pro tanto an international organ if it acts on international instructions. ${ }^{71}$ It remains such even if it deals entirely with national questions or invokes national law. Nevertheless, these variations or peculiarities deserve notice in any classification of international bodies.

One other possible and useful classification of international organizations flows from this same threefold analysis of governmental function with reference to law; it is, perhaps, but another aspect of the same thing. International organizations are either political or legalistic. That is, they are concerned either with the formulation, expression, synthesis, and adoption of national and international policy (ultimately involving creation of international law), or they are solely concerned with discovery and administration of existing law. Of course these two phases are inextricably intermingled in actual practice, at least in the sense that existing law is almost never so full or precise as to relieve administrative and judicial agencies of the need to interpret its provisions, giving rise to policy-determining activity on the part of the administrator and

ternational du Travail, La Reglementation des Migrations, Vol. III: Les Traites et les Conventions Internationales, 1929.

${ }^{68}$ League of Nations, Report of World Economic Conference (1927), Vol. I, pp. $30-56$.

${ }^{69}$ Compare the situation in the Pan American Union prior to 1923. G. H. Stuart, Latin A merica and the United States (2nd ed., 1928), p. 21.

${ }^{70}$ See the many cases of sole arbitrators, e.g., J. B. Moore, International Arbitrations (1898), p. 350.

${ }^{71}$ Not, however, if it acts merely by authorization or permission of international law, as do all national administrative agencies. Thus a national consul acts under authority of international law in viséing passports of aliens desiring to enter his country, but in so doing he is administering the national law and instructions of his own state; while an agency or official who carries out the law and instructions of an international body is ad hoc an international administrative organ. 
law-making on the part of the judge. ${ }^{72}$ But the distinction is still important: policy formation, or law-making agencies, on one side, and law-administering agencies on the other; that the two types of function are often deliberately shared between the two sets of agencies, in addition to the inescapable blurring of the distinction already mentioned, does not alter the situation profoundly. Here also the organizations actually listed afford numerous examples.

Of course it is difficult to apply the foregoing classification to many existing international organizations or unions of states taken just as they are found, because these organizations embrace organs or agencies, both coördinate and hierarchical, performing different functions. Thus the International Labor Office boasts a General Conference (legislative), a Labor Office (administrative), and even a Commission of Inquiry (of a semi-judicial character). Indeed, all but a very small proportion of existing international organizations possess at least legislative and administrative organs. This does not mean that the suggested analysis is impossible of application or unfruitful of results, but merely that it must be applied to the individual organs of international unions rather than to the complete systems embracing those organs.

This explains in part, perhaps, the employment of other classifications in the Handbook and in common thought. Thus in the Handbook we find ${ }^{73}$ the (official) organizations classified under two headings, with a further subdivision in the second class: (1) institutes maintained by governments and placed at the disposal of the League of Nations; (2) organizations established by collective treaties, distinguished as (a) bureaux under the direction of the League, and (b) others. In the first group are placed the Institute of Intellectual Coöperation, the Educational Cinematographic In-

${ }^{72}$ For practical reasons, these agents do not like to declare "no law" and wash their hands of a given problem, and sometimes existing codes of administration seem to make this impossible, however superior in sound juristic logic such action would be to the current practice. Of course if there is no law, the administrative agent need not move unless invoked to do so by an outside party, and when a court is asked to grant relief or apply a penalty it may conclude that no case has been made out justifying that action. But even these possible methods of escape do not entirely avert the action in question. Moreover, in international adjudication the court is seized of a cause by joint submission rather than unilateral action, and hence finds it harder still to escape by this avenue. See interesting discussion in A. A. Roden, "La Compétence de la Cour Permanente," Revue de Droit International et de Législation Comparée, Vol. 12, p. 757 (1931).

${ }^{73}$ Handbook, p. 9. 
stitute, and the Institute for Unification of Private Law. In the second are placed some thirty organizations, six or seven of which have been put under League direction, leaving a score outside, under the heading "Others."

It has been suggested already that this classification might be regarded as lacking something in realism and significance. It was, however, adopted in part for purely formal or administrative reasons; the distinctions made in the second part of the list derives from this source. At the same time, it does not appear that the placing of an organization under the direction of the League in accordance with Article XXIV of the Covenant constitutes any very important change in its character or even in its status. The organization continues to function as it did before and receives little but moral support or leadership from Geneva. Add to this the fact that the application of Article XXIV has varied somewhat in the different cases where it has been undertaken. ${ }^{74}$ On the other hand, the small group at the top seems to be set apart for insufficient reasons. All three rest upon the action or agreements of the nations members of the League, and are subject to their control. ${ }^{75}$ The fact that they are supported by French and Italian funds does not seem to justify their being set apart from the organizations in Group 2, which might well, therefore, be made to consist of three subdivisions.

The organizations in the Handbook are classified also by subjectmatter. ${ }^{76}$ The results are revealing, although the fact that the hundreds of unofficial organizations are mingled with the score of official organizations somewhat obscures the situation. Likewise the coëxistence of two or more organizations dealing with different aspects of the same subject, in four different cases, distorts the results to a certain degree. ${ }^{77}$ From one point of view, this classifica-

74 See discussion in same, pp. 6-8, and Ray, p. 667, etc.

${ }^{75}$ Summarized, with ample documentary citation, in Ray, p. 676, etc.

${ }^{78}$ Handbook, pp. 3, 296-312.

77 Air Questions, International Conference on Private Law affecting.

Air Questions, International Technical Committee of League Experts on.

Danube, International Commission of the.

Danube, European Commission of the.

Danube, Permanent Technical Hydraulic System Commission of the.

Postal Union, International Bureau of the Universal.

Postal Union, International Bureau of the Pan-American.

Railway Transport, Central Office for International.

Railways, International Conference for Promoting Technical Uniformity on. 
tion is very significant, revealing as it does in what matters international organizations have arisen in greatest numbers ${ }^{78}$ and where not, the above qualifications being duly taken into account and also the fact that the whole League organization and its subdivisions are omitted. From another point of view, however,-that, namely, which asks what these organizations do and can do in regard to the subjects intrusted to their care-it is not very informing.

One can, however, hardly imagine the editors of the Handbook classifying the international organizations or their agencies according to their functions in making or applying law, any more than one can imagine the average lay observer of international affairs doing so. It sometimes seems that such analytical classification is intentionally avoided by these observers. This may or may not be true, but the general and persistent ignoring of considerations of this order by most of the personnel of the international organizations existing today can otherwise only be explained by an amazing ignorance and unawareness of any systematic theory of state organization and action. Perhaps a desire not to see the actual powers of certain agencies defined too precisely or too narrowly has something to do with it. Perhaps hostility to effective international government in other quarters may be cited along with this, as a further reason for refusal to look at the problem analyti cally.

A final classification is suggested in the Handbook, namely, the geographical. ${ }^{79}$ Without attempting to apply this standard rigorously, it may be seen clearly that most of these organizationsofficial and private-are made up predominantly of European elements, have their headquarters in Europe, and carry on most of their activities there. The fundamental reason for this is obvious-the large concentration in Europe of independent nations and international relations. Further inferences might be drawn hereerroneous as well as sound. For the moment, the ma'ter may hr. allowed to stand.

How much, or just what, an organization may or can do with respect to the subject intrusted to its care is much more difficult

${ }^{78}$ Decreasing frequency groups: Humanitarianism, Religion, Morals; Arts and Sciences; Labor; Communications and Transit; Law and Administration; Education; Medicine; Sport; etc.

79 See pp. 329-348. 
to determine. Make law and apply law, perhaps, in a general sense. But how far may it go in accomplishing these ends? How far may it go legally and how far may it go practically? What are the limits of its legal authority and of its actual (including physical) power?

As has been indicated, few, if any, of the ostensibly law-making international organs have power to make law except with subsequent ratification by the participating states. ${ }^{80}$ Indeed, the composition of almost every international conference (equal, and strictly instructed, delegations from participating states) is such that it is hardly accurate to think or speak of the organ as such taking legislative action. It is rather the states themselves, in conference assembled (and later back in national capitals on the stage of ratification), which take the action. According to this test, virtually all conferences would fall in the same class: conferences with inconclusive authority.

On the other hand, various administrative and judicial bodies are clearly given, or at least clearly exercise, a degree of law-making power (power to make regulations or rules of procedure) which could be retracted or cancelled only after the fact and at times by the most cumbersome of processes. ${ }^{81}$ This is said without reference to the possible legislative force inhering in administrative rulings by way of interpretation of existing laws or judicial decisions of the same type, already discussed. But it is also true that this incidental-sometimes it seems to be even accidental-power of legislation is so general among all administrative and judicial bodies as to lose its value as a means of identification. It might be added that this type of power is possessed in a certain degree also by international legislative bodies. ${ }^{82}$

Administrative and judicial authority is bestowed much more frequently in terms which make its exercise practically final. The possibility of appeal is sometimes provided in connection with

${ }^{80}$ Apparent exceptions may be found in the Recommendations of the General Conference of the International Labor Organization. But this is more apparent than real. International Labor Organization, Dix Ans d'Organisation Internationale du Travail (1931), p. 65.

${ }^{81}$ Legislative power in executive and judicial bodies. Convention of the International Institute of Agriculture, Arts. VI and VIII, and Statute of the Permanent Court of International Justice, Art. 30.

${ }^{82}$ Of conferences: rules of procedure of the General Conference of the International Labor Organization, as published by the International Labor Office, based on International Labor Organization Constitution, Art. 403. 
actions of international administrative ${ }^{83}$ and judicial bodies, ${ }^{84}$ but perhaps as often not. There remain always certain rights of a nation to defy such rulings for reasons of self-preservation. ${ }^{85}$ But this is a precarious matter, resembles the alleged right of the individual to disregard what he believes to be an unjust law, and approaches the ethical rather than the legal. Speaking generally, international administrative and judicial organs exercise definite authority in their activities, as do international legislative bodies when performing administrative tasks. This is particularly true for administrative organizations to which has been delegated the exercise of territorial or personal jurisdiction over individuals (in contrast to those ministering to the nations as such) $;^{86}$ although this difference does not, otherwise, seem to hold great importance as a basis of classification, being simply a mode or aspect of the difference of degree of authority here being considered.

When the question of factual influence and power is raised, the answer is much the same, with one very important addition. International legislative bodies, i.e., international conferences, do not wield decisive influence, and have no means of compelling respect for their decisions. Ratifications are delayed and withheld almost without hesitation or thought for any prestige or moral importance of the conference. No conference has anything like the assumed power to command-the feeling of authority which is matched by a similar respect among the objects of its commands-possessed by national legislative bodies. By contrast again, the actual influence of international administrative bodies and international courts is great, the deference paid to them substantial. Where administrative bureaus are created for performance of indecisive functions, such as collection of information, no great respect is paid to them, and of ten their light requests are disregarded as the more exacting demands of other bodies are not. But when bureaus and courts speak with a pretense of authority, they seem to exercise sufficient influence to be obeyed.

The great qualification to all this is found in the fact that none

${ }^{83}$ Convention of the Universal Postal Union (1929), Art. 10.

${ }^{84}$ Statute of the Permanent Court of International Justice, Art. 61. See also J. H. Ralston, Law and Procedure of Arbitral Tribunals (1926), p. 207.

${ }^{85}$ This is simply a phase of the general right of self-preservation. See discussion in P. Fauchille, Traité de Droit International Public, 1922 (Bonfils, Manuel, 8th ed.), p. 410 .

${ }^{86}$ Best exemplified in the river commissions: above, notes 65 and 66. 
of these bodies possesses equipment or powers of physical action for enforcement of its decrees or legal power to call upon either national or international agencies for such action (sanctions) ${ }^{87}$ So long as the psychological-political, moral, or what not-influence of these bodies is adequate, this is not of great importance; but it must always be borne in mind because of its importance in the extreme case and because of its indirect influence all along the line.

All this being true, the classification of international organizations by reference to degree of legal authority of factual power seems too complicated and inconclusive to be valuable. Variations among individual conferences, bureaus, and courts would appear, as among these types of organs in general, but no great or significant distinctions could be made beyond those recited above, which, with one exception, are of such a nature as to render classification difficult rather than simple. The problem assuredly repays study, but the facts are not such that the results can be formulated in terms of a classification.

It may already have been felt that there were so many qualifications necessary likewise in connection with the legislative-administrative classification that it also was less than entirely satisfactory. Have not all of these suggested standards-relations to law, relations to the League, subject-matter, degree of authority, and of power-failed to give us what we want? Perhaps a simpler and less technical, and at the same time a more pragmatic, standard may be useful. Let us ask just what kind of services, in a quite common sense of that term, existing international organizations offer and see whether a significant grouping will not emerge from the replies.

International organizations, or some of them, concentrate upon collection and distribution of factual data. Others conduct studies of (the data of) social problems and make their findings publicly available. Still others make recommendations to states or to other organizations based on their findings, ${ }^{88}$ and perhaps facilitate the

${ }^{87}$ For two remote approaches to such an arrangement, see Covenant of the League of Nations, Art. XIII, par. 4, and International Labor Organization Constitution, Art. 414.

${ }^{88}$ The whole question of the relations among international organizations has been passed over lightly here (but see above, near notes 15 and 16) because it does not offer much aid in classification. If organizations are intimately related, they are not likely to be distinct organizations. If one organization controls another, this is sure to be true; also if one acts as agent for, or servant to, another. See, for example, Covenant of the League, Art. VI. 
adoption of such findings by the states, by sponsoring conferences where they may be discussed. And finally, others supervise the carrying out of such results or carry them out themselves. Is this not a more significant classification than any suggested so far? It turns, obviously, upon the type of service performed in relation to the utilization of scientific truth in international social practice, and perhaps this is about as fundamental a test as could be adopted as the basis for our analysis.

There are, of course, two or three general qualifications which have to be admitted here as in connection with the classifications already attempted. There are organizations which perform two or more of the services just outlined. ${ }^{89}$ There are those whose services do not seem to fit exactly into this scheme at all-the general difficulty of any classification. ${ }^{90}$ And there is the fact, likewise noticed in another connection, that the people engaged in the operation of these organizations are, most of them, so interested in the subject-matter of their activity, or in good international relations and feelings, or so naïve and unconscious of such problems of theory, that the work is carried on without that distinctness of character which would be evident if those engaged in it were conscious of its logical place in the general scheme of things.

More serious still is the fact that this classification appears too weak in its separate items and in its general structure to break across or disrupt the more fundamental legislative-administrative classification; collection of data, study, recommendation-these are not vigorous concepts, nor are the relations or transitions from one to the other very compelling or inevitable.

What is finally decisive is thefact that this classification turnsout, upon examination, to be but a variant upon the fundamental one just mentioned. Adoption of findings and carrying out the results thereof really amount exactly to legislation and administration, and nothing else. All else is merely preparatory and subsidiary. These steps may be taken by the organization itself, or, if it be merely advisory, by the states, but their nature is clear. Similarly, the international organization may advise individual states, their legislatures, or their administrativs agencies, as to how to attain their objectives most effectively, or even seem, in rare cases, to act

${ }^{80}$ Convention of the International Institute of Agriculture, Art. IX.

${ }^{\circ}$ No court, for example, would fit in to this scheme. 
as an agency in a national governmental system;91 but the nature of the organization will still be most clearly understood if related to the main classification already employed. The last suggested classification is but an elaboration upon the earlier one.

This elaboration may be useful. The task of international organization is, in general terms, to facilitate the communication of national policies and views by one state to another, their reconciliation, synthesis, and adoption as international law, and the execution of the latter. ${ }^{92}$ For progress in this direction, most emphasis must be placed upon the process of reconciliation of discordant views and policies, in view of the seeming great discord actually existing among such policies. It is precisely by the collection and distribution of data, in the study of problems and the making of recommendations based thereon, by public agencies or (it may be admitted in this connection) by unofficial scientific agencies, that this may best be promoted. And perhaps agencies for study and recommendation rather than conferences for discussion are the most effective agencies that could be used here. Hence this analysis emphasizes one phase of the activity of international organization which is neglected in the somewhat brutal or over-simplified "legislative-administrative" analysis, and this (in the present circumstances) not the least important part. ${ }^{93}$

VI

In summary, it would appear that effective analytical and classificatory study of the existing international organization or organizations has been somewhat lacking in the past, that this is explainable by various different reasons, including the practice and study of international organization by persons not adequately trained in systematic political and juristic theory, and that this has led to disappointing, if not dangerous, results, such as misconception of the parts to be played by men and agencies alike. The proper constitution or composition of international organizations, their proper organization, their proper conduct or operation,

${ }^{91}$ See position of the Quarantine Council in Egypt: Conference Sanitaire Internationale (1926), pp. 69, 508, and $\mathrm{Z}$. Loutfi, La Politique Sanitaire Internationale (1906), p. 106.

${ }^{92}$ See brief summary in Encyclopaedia of the Social Sciences, 1930, Vol. VIII (1932), p. 177 (article "International Organization").

${ }^{93}$ Argued more fully, in a particular case, in P. B. Potter, Revision of Treaties, 1933 (pamphlet), p. 16. 
and hence satisfactory results, all depend upon an understanding of the nature of the process of government in general and of its various detailed aspects in particular. If a conference is manned from among persons of no capacity as political leaders or legislators, but of rigid administrative temper - if a court is organized like a representative assembly, if the activity of a bureau is conducted in the spirit of a debate - things will not go well. ${ }^{94}$ Contemporary international organization is being conducted largely by persons who are rather absorbed in some specific cause (in terms of subjectmatter) or in the general cause of international coöperation, but who know and care little about the technique of conducting public affairs in an orderly and systematic manner. National government suffers from this deficiency also, yet is far ahead of international coöperation in this respect. And the science of international organization is marred by similar, though less serious, inadequacies of understanding on the part of students of the problem. It seems that changes must take place here before changes can be looked for in the results achieved. ${ }^{95}$

${ }^{94}$ Deliberate efforts to utilize an organ for a function for which it was not intended may-or may not-succeed better; thus friends of international coöperation holding posts on administrative bodies at times attempt to have such agencies exercise power to make new law and engage the responsibility of member-states thereby, beyond the point to which the latter have previously been willing to go, and sometimes this manoeuvre succeeds. See, above, p. 32, and "Revision of Treaties," in Geneva Special Studies, Vol. 3, No. 9 (1932), p. 10. There are also those-sometimes placed on such bodies internationally-who are, per contra, strict constructionists for opposite reasons.

${ }_{95}$ The draft-text of this paper was discussed extensively with the members of the writer's seminar in international administration at the Graduate Institute of International Studies, Geneva, and embodies numerous contributions made by them. 